\title{
Evaluation of leaves extract of Solanum melongena and Cyperus rotundus against Sitophilus Oryzae L.(Coleoptera:Curculionidae)
}

\author{
Olfat M. EI Monairy and Aida S. Kamel \\ Benha University, Faculty of Science, Entomology department.
}

\begin{abstract}
This study was conducted to evaluate Toxicity and repellent effects of two locally available plants namely Solanum melongena (Solanacae) and Cyperus rotundus (Cyperacae) against adults of Sitophilus Oryzae. The plant extracts were applied at five concentrations on rice grains which 2.5, 5, 10, 25 and 50\%) for each.. Adult insects were exposed to treated rice grains and mortality was calculated after $1,2,6,10$ and 17 days of exposure. The results indicated that the toxic and repellent effects were proportional to concentrations and time intervals. Higher concentrations had stronger toxicity and repellent effects than lower concentrations. Rice grains weevils which were treated with two plant extracts exhibited significant mortality percentage of 76.6 and 46.66 , respectively, after 17 days at 50\% concentration. These indicated that $S$. melongena was more toxic than $C$. rotundus against adult insects. The highest concentrations of $50 \%$ extracts giving 56.6 and 51.6 repellency respectively in both plant extracts percentage
\end{abstract}

Keywords: Sitophilus oryzae, Extracts, Solanum melongenae, Cyperus rotundu, mortality, repellency.

\section{INTRODUCTION}

The rice weevil, S. oryzae L. (Coleoptera: curculionidae), is the most widespread and destructive major insect pest of stored cereals through out the world. S. oryzae has been reported as one of the severe pests of the cereal grains and their products (Bloch, 1992). To control these pests, synthetic insecticides are used during storage of grains. They cause residual pollution of the environment, toxicity to consumers and residues on grains. Moreover S. oryzae has been reported to develop resistance to synthetic insecticides Benhalima et al., (2004). Different types of plant preparations are being investigated for their insecticidal activities including their action as fumigants, repellents, antifeedants, antiovipositions and insect growth regulators (Isman, 2000; Koul, 2004; Negahban and Moharramipour, 2007). The plant derived chemical has been used as potential protectant (insecticides and antifeedants) often begins with the screening of plant extracts (Pavela, 2007). Jilani and Su, (1983) and Jilani et al., (1988) conducted insect repellency assay using extracts of different plants on stored product pests. Talukader and Howse (1994) mentioned the toxic and repellent properties of extracts of Aphanamixis polystachya against S. oryzae. Pretheep-.Kuma et al. (2004) observed promising results in the protection of the rice against S.oryzae using protein enriched pea flour extract.

Plant family, Solanacae is a wide and chemically rich family that has been reported to contain gluco-alkaloids, solanine, solanidine, nicotine, somniferine, somine, withananine, withanine, withananinine, volatile oil, tannin and considerable amount of potassium nitrate Chopra et al.(1965) also reported the roots contain two saponoids, dulcamaric acid, dulcamaretinic acid and gluco-alkaloid solaceine. 
Nut grass ( Cyperus. rotundus) also called purpel nutsedg, belonging to family Cyperacae .This grass is beneficial as an ingredient in a herbal medicine. Where Visetson et al.(2001) showed 10 active principles had accumulated in tubers as,4,11selinnadien3-one concentration was higher in their extracts.Also the crude extracts of nut grass (Cyperus rotundus L.) tubers gave $80 \%$ mortality to diamondback moth larvae in one hour post treatment .They indicated that the active compound,4,11selinnadien3-one, was responsible for killing the larvae Ohsawa et al. (1996).

The aim of this work is to use plant extract Solanum melongena belonging to family Solanacae and Cyperus rotundus belonging to family Cyperacae to study their efficacy against $S$. oryzae as one of the most important cereal pests of world- wide distribution.

\section{MATERIALS AND METODS}

\section{Insect culture}

Adults of $S$.oryzae were collected from naturally infested rice grains .Insects were reared in the laboratory on clean, un-infested and sterilized rice grain. Twenty adult of insects were released in 50g.of rice grains which kept in glass jars (21x10 $\mathrm{cm})$ capped with cotton cloth to insure ventilation. All the jars were maintained at room temperature $25 \pm 1{ }^{\circ} \mathrm{C}$ and $65 \% \mathrm{RH}$ and continuous darkness. All individuals used in the test were 7-10 days old

\section{Preparation of plant extracts}

The leaves of Solanum melongena (Solanace) and Cyperus rotundus (Cyperaceae) were collected from Benha, Qalubia governorate, and washed with distilled water and air dried for six days. Plant materials were powdered using an electric grinder. The powdered materials were separately subjected to acetone extraction with soxhlet apparatus for 15-18 hrs (Evans and Raj, 1988). Crude extracts were concentrated by using a rotary evaporator. Dark green residue obtained were stored in glass vials and maintained at a refrigerator $\left(4^{0} \mathrm{C}\right)$ until further use.

\section{Bioassay}

Five concentrations, $(2.5,5,10,25$ and $50 \%)$ were made in analytical grade acetone for bioassay test. The extracts were mixed for about five minute with rice grains separately $(0.2 \mathrm{ml} / 50 \mathrm{~g}$ rice) and air dried for 10 minutes. $S$. oryzae (20 in number) were released into plant extracts treated rice containing glass jars covered with cotton clothes tide with rubber bands. Three replications were used for each concentration of both plant extracts .The same volume of acetone treated grains was served as control. Observation were recorded at intervals of 1, 2, 6, 10 and 17 days after the treatments. All mortality observations were corrected by Abbott's formula (1925), and subjected to probit analysis by (finney,1971)

\section{Method for repellency test}

Repellency test was conducted following the method of Talukdar and Howse (1993), Amin et al., (2000). Solutions of previous five concentrations were prepared from both plant extracts .The repellency effect against adults of $S$. oryzae were investigated. Where nine centimeter diameter filter paper were marked into two portion. 0.2 millilitre solution of each extract was applied to one half of the filter paper (treated half) and on the other half 0.2 milliliter of acetone (controlled half). The treated filter paper were then air dried and placed in a petri dish. Twenty (20) insects were placed in the middle line of filter paper. Number of insects on each side were counted at one hour intervals up to the five hours after treatments. Percentage (\%) repellency was calculated by using the following formula from Abbott, (1925). 
Percent Repellency $=(\mathrm{A}-\mathrm{B} / \mathrm{A}) \mathrm{X} 100$.

$\mathrm{A}=$ Average number of insects present on untreated portion.

$\mathrm{B}=$ Average number of insects present on treated portion.

The percentage of repellency were then categorized according to the following scale by method of Amin et al., (2000) and Roy et al., (2005).

\begin{tabular}{|c|c|}
\hline Class & Repellency Rate $(\%)$ \\
\hline 0 & $>0.01$ to $<0.1$ \\
I & 0.1 to 20 \\
II & 20.1 to 40 \\
III & 40.1 to 60 \\
IV & 60.1 to 80 \\
V & 80.1 to 100 \\
\hline
\end{tabular}

\section{RESULT AND DISCUSSION}

All treatments revealed significantly $(\mathrm{p} \leq 0.05)$ high mortality percentages after 17 days of exposures, were $76.66 \%$ and $46.66 \%$ at conc. $50 \%$ in Solanum melongena and Cyperus rotundus, respectively (Fig. 1). While the lower mortality percentages were $26.60 \%$ and $10.0 \%$ at $2.5 \%$ in both extracts, respectively when both compared to the control.
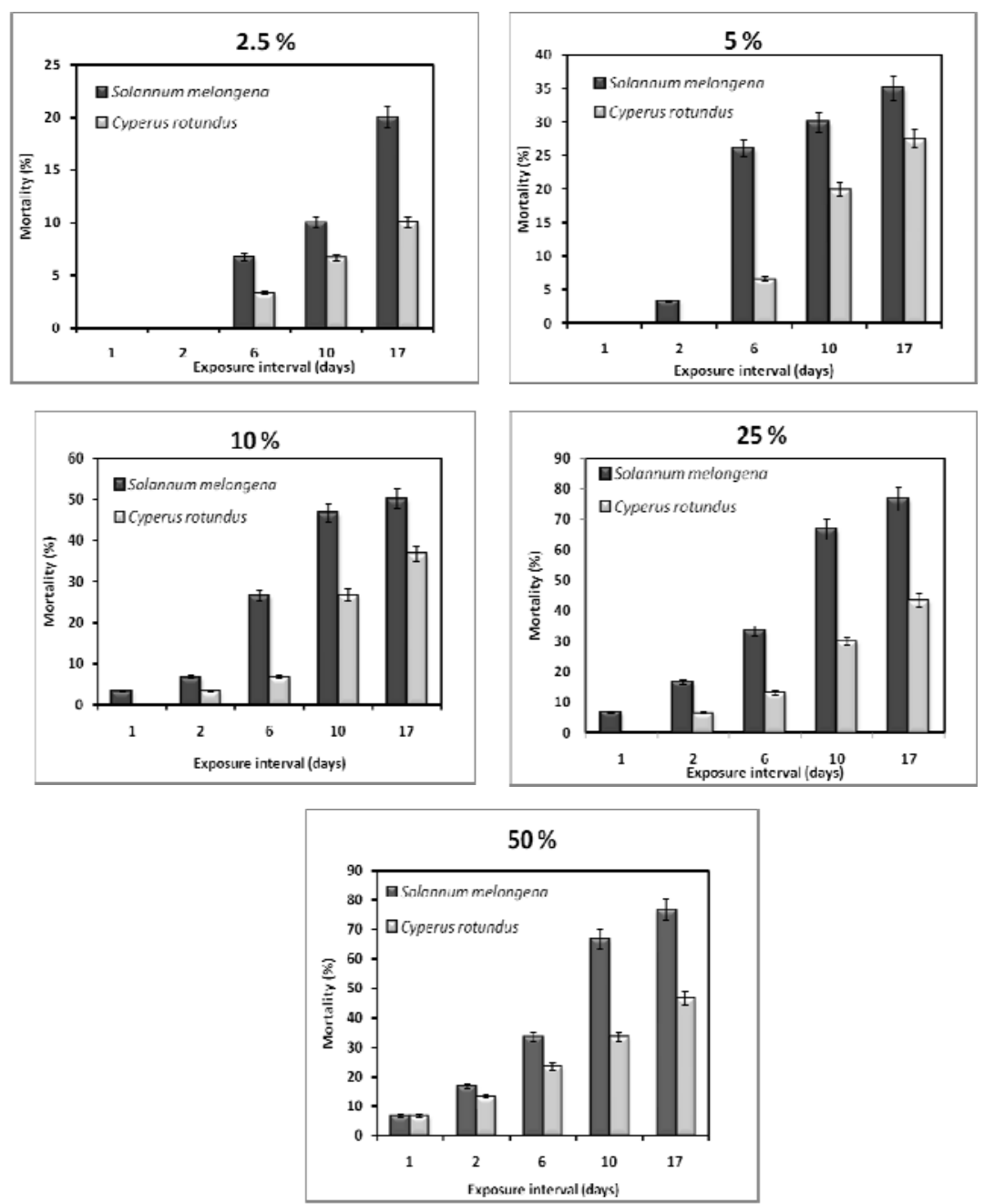

Fig. 1: Mean Mortality ( \pm S.E) of S. oryzae exposed for 1, 2, 6, 10 and 17 days on rice grain treated with concentrations $2.5,5,10,25$ and $50 \%$ of both plant extracts. 
In general mortality rates were increased by increasing the concentrations of both plant extracts and exposure time.

These results agree with (Yanckanchi and Gadach 2010) when they used ethanol extracts of Withonta somnifera L. (Solanacae), they found the mortality rates were increased with increasing the concentration of plant extracts and exposure time. This conclusion was also confirmed by (Khoshnoud et al., 2008) and (Gupta and Srivastava, 2008). From Fig.1 it is obvious that plant extract of S. melongena was more effective against $S$. oryzae than $C$. rotundus. Where the rice grains weevils treated with acetone extracts of S.melongena and C. rotundus produced higher mortality rate at high concentration with $\left(\mathrm{LC}_{50}\right)$ was 14.23 and 54.69 , respectively, after 17 days.

S. melongena leaves extracts showed maximum insecticides activity after 17 days that might be due to the presence of gluco-alkaloides, solanine and tanine. This conclusion is confirmed by finding of Nenaah, (2011) who reported the presence of toxic effects of glycoalkaloids isolated from Solanum tuberosum L. and lycopersicon esculentum Mill.(Solanacae) against red flour beetles, Tribolium castaneum Herbst and rice weevils, $S$. oryzae $\mathrm{L}$. While $C$. rotundus extracts at highest concentration give less mortality effect than S.melongena (46.66\%) at high concentration, this might be due to presence of 4,11 selinnadien 3-one (Vesitson, et al. 2001).

The present results in this study was showed that the botanical extracts were effective aganist $S$. oryzae but its effectiveness was highly determined by the concentration rate and exposure intervals .One of the most interesting findings of the current study was the dissimilar efficacy of botanical materials among plant species so that, S. melongena was more effective against $S$. oryzae on treated grains than C.rotundus. Moreover, results showed that for this insect concentration rates and longer exposures intervals were needed to obtain a satisfactory level of mortality rates However, the present result indicated that higher concentrations of these plant extracts for a relatively short period are much more effective than lower concentration for along period, similar observation on other plant extracts on several insects have been reported for example Khoshnoud et al. (2008) showed that plant extracts of Verbascum cheiranifolium Boiss and Verbascum speciasum Schard possess toxic principles with significant insecticidal effect against S. oryzae

Repellency test.

In the current study, we observed that the decrease in rice grains damage after the treatments. Both plant extracts showed repellency effects against $S$. oryzae.

Leaves extract at $2.5 \%$ in C.rotundus showed that the lowest repellency percentage 6.78 and followed by S. melongena 13.3 against S. oryzae. On the other hand the higher repellency effects were obvious at higher concentrations in both plants (51.7 and 56.6, respectively at 50\%).

The repellent action increased with increasing in concentrations and time intervals of both applied extracts (Table 1\&2). This results were agreed with Rahman et al. (2007), they investigated ethanol extract of Melgota for its insecticidal activity against $S$. oryzae. They found the toxic and repellent effects were proportional to the concentrations and the higher concentration had stronger effect than lower. Also mortality percentages increased with the increasing in time intervals after treatments. While Roy et al., (2005) reported repellent effects of Shyialmutra against rice weevil with concentration $3 \%$ leaf extract.

The biological activity of plant extracts might be revealed that the various compound present in the extracts have toxic and repellent effect. Where family Solanacae was reported to contain solanine, volatile oil and saponoid (Chopra et al. 
1965). These compounds might be independently or jointly contribute to cause toxic and repellent actions against $S$. oryzae. The percentage of repllency of $S$. oryzae in case of S. melongena extract at concentrations 2.5, 5 and 10 were laid in repellent class I, I and II, they were consider slightly repellent. While concentrations 25 and $50 \%$ were laid in repellent class III, they were considered moderate repellent (Table 1). Also in case of $C$. rotundus. the percentage of repllency was in repellent class 0 , II,II at lower concentrations 2.5, 5 and 10, respectively while II and III at concentrations 25 and $50 \%$ (Table 2), according to (Parugrug and Roxas 2008). The sluggish movement and repellent action of C.rotundus extract might be revealed to contain Cyperine, Tetrahydroxycyclopentadenon were observed in GC mass chromatograph reported by (Vesitson et al. 2001).

Table 1: Repellency of different concentrations of acetone extracts of S. melongena leaves on rice weevil.

\begin{tabular}{|c|l|l|l|l|l|l|c|}
\hline \multirow{2}{*}{$\begin{array}{c}\text { Extract } \\
\text { concentration\% }\end{array}$} & \multicolumn{5}{|c|}{ After treatment } & \multirow{2}{*}{$\begin{array}{c}\text { Mean } \\
\text { Repellency }\end{array}$} & $\begin{array}{l}\text { Repellenc } \\
\text { y Class }\end{array}$ \\
\cline { 2 - 7 } & $1 \mathrm{~h}$. & $2 \mathrm{~h}$ & $3 \mathrm{~h}$. & $4 \mathrm{~h}$ & $5 \mathrm{~h}$ & $\mathrm{I}$ \\
\hline 2.5 & 11.3 & 11.3 & 11.3 & 11.3 & 21.4 & 13.3 & $\mathrm{I}$ \\
\hline 5 & 11.3 & 11.3 & 21.4 & 11.3 & 21.4 & 15.3 & II \\
\hline 10 & 21.4 & 33.33 & 21.4 & 41.3 & 41.3 & 31.7 & III \\
\hline 25 & 33.3 & 41.3 & 41.3 & 48.4 & 48.4 & 42.54 & III \\
\hline 50 & 41.2 & 48.4 & 48.4 & 70.1 & 75.1 & 56.6 & \multicolumn{1}{c}{} \\
\hline
\end{tabular}

Table 2: Repellency of different concentrations of acetone extracts of C.rotundus leaves on rice weevil.

\begin{tabular}{|c|c|c|c|c|c|c|c|}
\hline \multirow{2}{*}{$\begin{array}{l}\text { Extract } \\
\text { concentration } \%\end{array}$} & \multicolumn{5}{|c|}{ After treatment } & \multirow{2}{*}{$\begin{array}{c}\text { Mean } \\
\text { Repellency }\end{array}$} & \multirow{2}{*}{$\begin{array}{l}\text { Repellenc } \\
\text { y Class }\end{array}$} \\
\hline & 1h. & $2 \mathrm{~h}$ & $3 \mathrm{~h}$. & $4 \mathrm{~h}$ & $5 \mathrm{~h}$ & & \\
\hline 2.5 & 0.0 & 0.0 & 11.3 & 11.3 & 11.3 & 6.78 & 0 \\
\hline 5 & 11.3 & 21.4 & 11.3 & 21.4 & 41.3 & 21.31 & II \\
\hline 10 & 21.4 & 21.4 & 21.4 & 41.3 & 41.3 & 29.36 & II \\
\hline 25 & 33.3 & 33.3 & 41.3 & 48.4 & 48.4 & 40.9 & II \\
\hline 50 & 41.3 & 41.3 & 48.4 & 57.1 & 701 & 51.6 & III \\
\hline
\end{tabular}

\section{REFERENCES}

Abbott, W. S. (1925). A method of computing the effectiveness of an insecticides Journal of Economic Entomology, 18.266-267.

Amin, M.R.; Shahjahan; Eltaj, M. H. F.; Iqbal T.M.T and Almagir, M. Hossain (2000). Bangaladesh J.Entomol, 10(1\&2):1-13.

Benhalima, H. M.Q.; Chaudhry, K. A.; Millis and N. Price (2004). Phosphine resistance in stored- product insect collected from various grain storage facilities in Morocco. J. stored prod. Res., 40(3):241-249.

Bloch, U. K. (1992). Integrated pest Management in food grains. Food and agriculture organization of the united Nation and Pakistan Agriculture research pp.117.

Chopra, R. N.; Badhwar R. L. and Ghosh, S. (1965). Leguminasae, In Kurp, C.R.R. (Ed). Poisonous plant of India. Vol I. ICAR, New Delhi.

Evan, D. A and Raj, R. K. (1988). Extracts of Indian plants as mosquitoes larvicides Indian Journal of Medical Research, 88:38-41.

Finney, D. J. (1971). Probit analysis $3^{\text {rd }}$ Edn., Cambridge University press, London, pp:318.

Gupta, L. and Srivastava, M. (2008). Efect of Withania somnifera extracts on the mortality of callosobruchus chinensis. Journal of Biopesticides, 1(2):190-192. 
Isman, M. B. (2000). Plant essential oils for pest and disease management. Crop Prot., 19(10)143-155.

Jilani,G. and Su, H.C.F. (1983). Laboratory studies on several plant materials as insect repellent for protection of cereal grains.J.Econ.Entomol.76:154-157.

Jilani, G.; Saxena R.C. and Rueda, B. P. (1988). Repellent and growth inhibiting effects of turmeric oil, sweeflag oil, neem oil and " Margosan-O" on red flour beetle (Coleoptera Tenebrionidae). J. Econ. Entomo 181:1226-1230.

Khoshnoud, H.; Ghiyasi, M.; Amimia, R.; Fard, S. S.; Tajbakhsh, M.; Salehzadeh, H. and Alhyary, P. (2008) The potential of using insecticidal properties of Medicinal plants against insect pests Pakistan. J. of biological Science pp1-5.

Koul, O. (2004). Neem:a global perspective. In : Neem, Koul, O. \& S. Wahab (Eds.) Today and in the New Millennium. Kluar academic publishers, Dordrecht, Boston, London, 53(10):1-19.

Negahban, M. and Moharramipour, S. (2007). Fumigant toxicity of Eucalyptus intertexta, Eucalyptius sargentii and Eucalyptus camaldulensis against stored product beetles. J. Applied Entomol., 131(4)256-261.

Nenaah,G. (2011). Individual and Synergistic toxicity of Solanaceous glycoalkaloids Journal of pest Science, 84:77-86.

Ohsawa, D.K. and Kato, I Yamamoto. (1996). Insecticidal compound in tuber of Cyperus rotundus L. against the diamondback moth larvae. J. pestic. Sci. 21:444-446.

Parugerug, L. M. and Roxas C. A. (2008). Insecticidal Action of five plants against Maize weevil ,Sitophylus zeamais Motsch. (coleoptera : Curculionidae) KMITL.Sci. Tech. J. 8 (1): 24-38.

Pavela, R. (2007). Possibilities of botanical insecticide exploitation in grain protection Journal of pest technology 1:47-52.

Pretheep-Kumar, P.; Mohan, S. and Ramaraju, K. (2004). Protein -enriched pea flour extract stored milled rice against the rice weevil ,Sitophilus oryzae. J. insect Sci., 4:26.

Rahman, S. S.; Rahman, M.D.M. Rahman Khan M. M.; Begum, S. A.; Roy B. and Shahe (2007). Ethanolic extracts of melegot (Macaranga postulate) for repellency, insecticidal activity against rice weevil (Sitophilus oryzae). Afr. J Biotech. 6(4):379-383.

Roy, B. Amin, R. and Uddin, M. N. (2005). Leaf extract of Shiyalmutra (Blumea Lacera) as botanical insecticides against lesser grain borer and rice weevil, J. Biol. Sci.5 (20):201-204.

Talukdar, F. A. and Howse, P. E. (1993). Deterrent and insecticidal effect of extract of pithraji, Aphanamixis polystacha against Tribolium castaneum. J. Chem. Ecol. 19:2463-2471.

Talukdar, F. A. and Howse, P. E. (1994). Laboratory evaluation of toxic repellent properties of the pithraji tree, Aphanamixis polystachya wall \& parker, against Sitophilus oryzae (L.) Int. J. pest Man. 40:274-279.

Visetson, S.; Milne M. and Milne J. (2001). Toxicity of 4, 11-selinnadin 3-one from nut sedge (Cyperus rotundusL.) tuber extracts to diamondback moth larvae (Phitella xyloslella L.), detoxification mechanism and toxicity to non target species. Kasetsart. Journal . Natural Science, 35(3):284-92.

Yankanchi, R.S. and Gadache, H. A. (2010). Grain protection efficacy of certain plant extracts against rice weevil, Sitophilus oryzae L. (Coleoptera: curculionidae) Journal of Biopesticides 3920. 


\title{
ARABIC SUMMARY
}

تقييم المستخلص النباتي لاوراق كل من نباتي الباذنجان والسعد المستدير ضدالطور البالغ لحشرة سوسة Sitophilus oryzae الأرن نيان

\author{
ألفت محمد المنيري و عايدة سعيد كامل

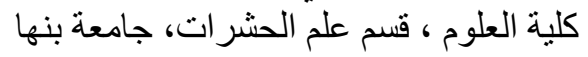

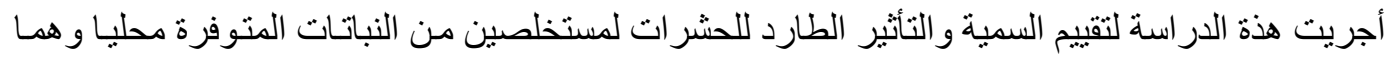

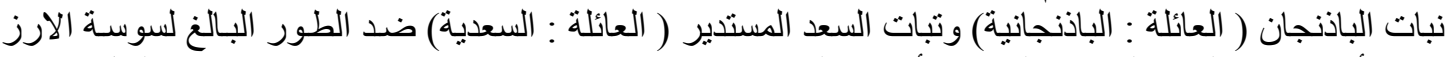

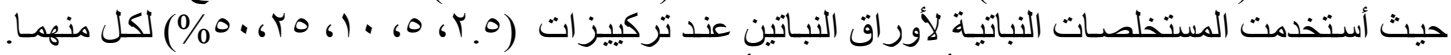

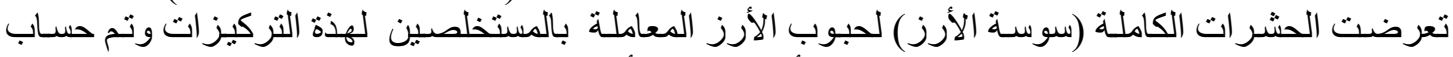

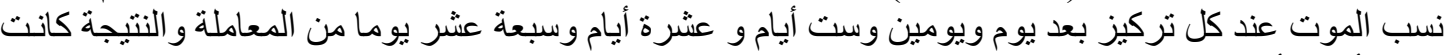

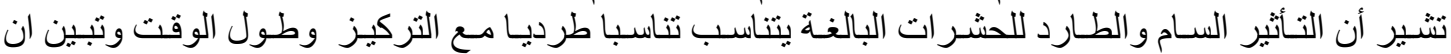

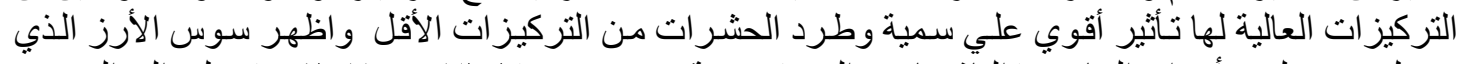

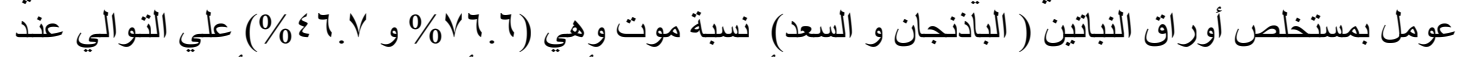

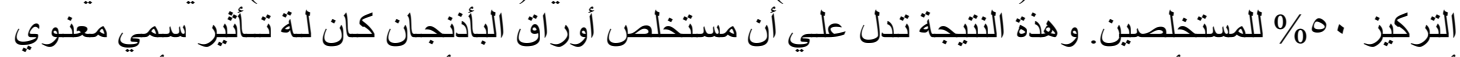

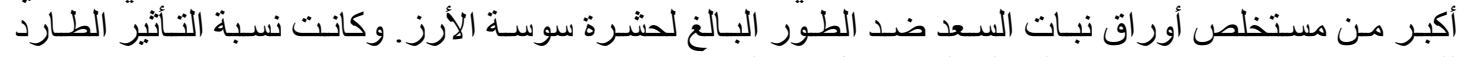

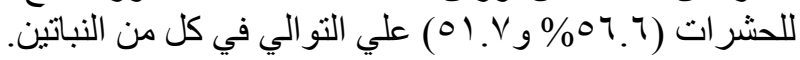

